\title{
Developmental and Regional Expression Pattern of a Novel NMDA Receptor-like Subunit (NMDAR-L) in the Rodent Brain
}

\author{
Nikolaus J. Sucher, ${ }^{1}$ Schahram Akbarian, ${ }^{3}$ Carlin L. Chi, ${ }^{1}$ Cynthia L. Leclerc, ${ }^{1}$ Marc Awobuluyi,, ${ }^{1,2}$ David L. \\ Deitcher, ${ }^{1}$ Michele K. Wu, ${ }^{1}$ Joseph P. Yuan, ${ }^{1}$ Edward G. Jones, ${ }^{3}$ and Stuart A. Lipton ${ }^{1,2}$ \\ 'Department of Neurology, Children's Hospital, 'Program in Neuroscience, Harvard Medical School, Boston, \\ Massachusetts 02115 , and ${ }^{3}$ Department of Anatomy and Neurobiology, University of California, Irvine, \\ California 92717
}

\begin{abstract}
A novel NMDA receptor-like (NMDAR-L) CDNA was isolated that contained an open reading frame coding for a predicted polypeptide of 1115 amino acids that shares $\sim 27 \%$ identity with NMDA receptor subunlts. In situ hybridization experiments indicated that NMDAR-L mRNA was expressed in the developing rodent CNS. On postnatal day 1 (P1), NMDAR-L mRNA expression was pronounced in the entorhinal cortex, the subiculum and the thalamus, in layer $V$ of the developing neocortex, in the superior and inferior colliculi, and various regions of the hindbrain, excluding the cerebellum. On P5, NMDAR-L mRNA was expressed in layer $V$ of the neocortex, in the entorhinal cortex, in the subiculum, and in the thalamus. On P14, NMDAR-L mRNA was expressed in layers II-VI of the neocortex, in the entorhinal and piriform cortex, in the subiculum and CA1 field, and in the nucleus of the lateral olfactory tract. In the adult brain, NMDAR-L mRNA was detected predominately in the nucleus of the lateral olfactory tract. Injection of NMDAR-L CRNA into Xenopus oocytes did not lead to the expression of homomeric glutamate-activated channels. However, coinjection of the triple combination of NMDAR-L with NMDAR1 and NMDAR2B CRNAs led to a striking decrease in the current magnitude compared to currents obtained after coexpression of the double combination of NMDAR1 with NMDAR2B. While the function of NMDAR-L remains to be established, its developmental and regional expression pattern suggests that NMDAR-L may influence axonal outgrowth and synaptogenesis during brain development.
\end{abstract}

[Key words: glutamate, NMDA, development, excitatory amino acid receptors, cortex, synaptogenesis]

Excitatory amino acid (EAA) receptors mediate excitatory synaptic transmission in the CNS, influence neuronal plasticity and survival, and are involved in key mechanisms of brain devel-

\footnotetext{
Received May 1, 1995; revised June 19, 1995; accepted June 22, 1995.

We thank Drs. Morgan Sheng and Nils Brose for sharing with us their experience with the immunoprecipitation and immunoblotting techniques, Dr. Nobuki Nakanishi and Saumya Das for helpful discussions and critical reading of the manuscript, and Dick Bemnett for expert technical assistance with the au tomated DNA sequencing. This work was supported by NIH Grant P01 HD 29587 (S.A.L. and N.J.S.), NS21377 (E.G.J.), and NARSAD (S.A.). The GenBank accession number for the NMDAR-L scquence is U29873.

Correspondence should be addressed to Nikolaus J. Sucher, Department of Neurology, Children's Hospital-Enders Building, Room 330, 300 Longwood Avenue, Boston, MA 02115 .

Copyright $\odot 1995$ Society for Neuroscience $0270-6474 / 95 / 156509-12 \$ 05.00 / 0$
}

opment (Kleinschmidt et al., 1987; Simon et al., 1992; Komuro and Rakic, 1993). EAA receptors have been classified into ionotropic and metabotropic receptor subtypes (Nakanishi, 1992). The ionotropic EAA receptors can be further distinguished according to their preferred agonists as NMDA, $\alpha$-amino-3-hydroxyl-5-methyl-isoxazol-4-propionic acid (AMPA), and kainate (KA) subtypes. Cell culture experiments indicated that activation of NMDA receptors promote neurite outgrowth (Lipton and Kater, 1989; Collingridge and Singer, 1990), and pharmacological blockade of NMDA receptors in slice preparations of the developing cerebellum was shown to cause an arrest in the migratory movements of granule cells (Komuro and Rakic, 1993). NMDA receptors appear to shape axonal growth patterns and to influence the formation of sensory maps. For example, NMDA receptor antagonists disrupted the formation of eye-specific stripes in the frog optic tectum (Cline et al., 1987), the eyespecific segregation of retino-collicular afferent arbors in the rat (Simon et al., 1992), the formation of the on- and off-ganglion cell specific sublaminae in the ferret lateral geniculate nucleus (Hahm et al., 1991), the formation of the whisker related pattern of thalamo-cortical efferents in the rat somatosensory cortex (Schlaggar et al., 1993), and the formation of ocular dominance columns in the developing cat visual cortex (Kleinschmidt et al., 1987; Bear et al., 1990).

EAA receptors likely consist of mixtures of subunits (Monyer et al., 1992; Wafford et al., 1993; Brose et al., 1994; Sheng et al., 1994). Five NMDA receptor subunits (NMDAR1 and NMDAR2A-D) and nine subunits of the AMPA/KA receptor family have been described. While the subunit composition has not been established for native EAA receptors, the NMDAR1 subunit appears to be essential for NMDA receptor function. Targeted disruption of the NMDAR1 gene in the mouse resulted in the absence of functional NMDA receptors and the early death of the mutant mice (Forrest et al., 1994; Li et al., 1994). NMDAR 1 deficient mice showed a severe defect in the whiskerrelated pattern of organization in the trigeminal nuclei of the brain stem, suggesting that expression of the NMDAR1 subunit is necessary for the formation of somatotopic maps in the developing rodent brain ( $\mathrm{Li}$ et al., 1994). The disruption of gene expression by targeted homologous recombination experiments is a useful tool to clarify the role of EAA receptor subunits in the developing brain. Another approach for clucidating the molecular basis of EAA receptor function during brain development is to identify receptor subunits that are selectively expressed during the period of brain development. Here, we report the 
molecular cloning, and the developmental and regional expression pattern of a novel NMDA receptor-like subunit, NMDAR$\mathrm{L}$, that is expressed in the first 2 postnatal weeks in many regions of the developing rodent brain but is virtually undetectable thereafter with the exception of the nucleus of the lateral olfactory tract. We speculate that NMDAR-L may be involved in mediating EAA receptor effects on neurite outgrowth, initial synapse formation, and the formation of connectivity patterns during brain ontogenesis.

\section{Materials and Methods}

Polymerase chain reaction, subcloning, and sequencing. Complementary DNA (cDNA) was reverse transcribed from total retinal or brain cell RNA with random primer hexamers following standard protocols. The PCR with the degenerate primers consisted of an initial denaturation at $94^{\circ} \mathrm{C}$ for $2 \mathrm{~min}$ followed by $94^{\circ} \mathrm{C}$ for $1 \mathrm{~min}$, annealing at $48^{\circ} \mathrm{C}$ for $1 \mathrm{~min}$, and elongation at $70^{\circ} \mathrm{C}$ for 2 min repeated $35-45$ times, and a final elongation step at $70^{\circ} \mathrm{C}$ for $10 \mathrm{~min}$. The PCR was performed in a Perkin Elmer 480 thermocycler in a $100 \mu \mathrm{l}$ reaction mixture consisting of buffer with $1.5 \mathrm{mM} \mathrm{MgCl}, 200 \mu \mathrm{M}$ of each dNTP, $2.5 \mathrm{U}$ Taq polymerase, and $45 \mathrm{pmol}$ of each primer. The sequences of the upstream and downstream primers were: DNMDA1 (peptide: CCYGFCID): $5^{\prime}$ TGT/C TGT/C TAT/C GGI TTT/C TGT/C ATI GA 3'; DNMDA4 (peptide: YTANLAAF): $5^{\prime}$ AAI GCI GCC/T AAG/A TTI GCI GTG/A TA $3^{\prime}$. The PCR products were subcloned into the SmaI site of the Bluescript plasmid [pBS; $\mathrm{KS}(+)$, Stratagene]. The cDNA inserts of $>40$ PCR product clones were sequenced with the Taq DNA polymerase cycle sequencing kit and the automated DNA sequencer from Applied Biosystems.

cDNA library screening. A random primed cDNA probe was prepared from a PCR product clone and was used to screen $1 \times 10^{6}$ phage clones of a rat forebrain cDNA library constructed into phage lambda Zap II. Hybridization positive clones were rescued into plasmids. Following restriction digests, the plasmids containing the longest inserts were chosen for DNA sequencing of both strands. One clone was used for subsequent screening of $1 \times 10^{6}$ phage clones of a second rat forebrain cDNA library in order to isolate additional independent clones. One such clone (clone 4 ) was again sequenced in both strands and used for in situ hybridization and oocyte expression experiments.

Sequence alignment. Progressive, pairwise alignments of the amino acid sequences of the ionotropic glutamate receptor subunits were performed with the program PILEUP (Genetics Computer Group, Sequence Analysis Software Package, Version 7.2, October, 1992; Program Manual for the GCG Package, Version 7, April 1991, 575 Science Drive, Madison, Wisconsin, USA 53711). The Databank accession numbers of the sequences used for the alignment were: $\mathrm{Z} 17238, \mathrm{Z} 17239$ (delta-1 and 2), X17184 (GluR1); M85035-M86037 (GluR2-4), Z11713 (GluR5), Z11548 (GluR6), M83552 (GluR7), U08257, U08258 (KA1 and 2), X63255 (NMDAR1), M91561-M91563 (NMDAR2A-C), D13212 (NMDAR2C), and D13213 (NMDAR2D).

Northern blot unalysis. Northern blot analysis was performed with total RNA (10 $\mu \mathrm{g} /$ lane) from rat brains at P3, P8, P12, and adult (Ad) and mouse brain at P0, P10, and adult. The integrity and equal loading of the RNA was confirmed by ethidium bromide staining of the gel prior to transfer onto nylon membrane. The full-length cDNA insert of clone 4 was used as template for the synthesis of a hybridization probe that was labeled with $\alpha-{ }^{32}$ P-CTP using a random priming kit (Amersham) to a specific activity of $>1 \times 10^{9} \mathrm{cpm} / \mu \mathrm{g}$. Hybridization was performed as described previously (Sucher et al., 1993). The blots were exposed to Kodak XAR film at $-80^{\circ} \mathrm{C}$ for $7 \mathrm{~d}$ with an intensifying screen (Du Pont).

Site-directed mutagenesis. The Chameleon double-stranded site-directed mutagenesis kit (Stratagene) was used to change the arginine in position 730 into an asparagine resulting in the mutant NMDAR$\mathrm{L} / \mathrm{R} 730 \mathrm{~N}$. The primer sequence used for mutation of arginine $(R)$ at position 730 into asparagine $(\mathrm{N})$ was CCT TCT GTT TGG GAA CAC AGC AGC C. A second primer (CCA CCG CGG TGG CGA CCG CTC TAG AAC TAG TGG ATC) was used to mutate the Not 1 site in the Bluescript plasmid in order to facilitate selection of the mutants. Introduction of the mutation was confirmed by DNA sequencing.

In situ hybridization. The mouse was chosen for the study of the anatomical distribution pattern of NMDAR-L mRNA because this species will be useful in future experiments aimed at the targeted disruption of this gene. Animals were sacrificed at postnatal days 1, 4, or 5 under deep anesthesia with ether, the brains removed, fixed overnight in $4 \%$ paraformaldehyde $/ 0.1 \mathrm{M}$ phosphate buffer at $4^{\circ} \mathrm{C}$, cryoprotected in $30 \%$ sucrose for $24 \mathrm{hr}$, and then frozen in dry ice. P14 animals and adult mice were sacrificed under deep anesthesia with Nembutal and then transcardially perfused with $20 \mathrm{ml}$ of saline (room temperature), followed by $50 \mathrm{ml}$ of chilled $4 \%$ paraformaldehyde in $0.1 \mathrm{M}$ phosphate buffer. Parasagittal brain sections from P1, P4, P5, P14, and two adult mice were hybridized with ${ }^{33} \mathrm{P}$-UTP-labeled sense and antisense cRNA probes transcribed from the full-length NMDAR-L cDNA clone that had been inserted into the pBS transcription vector using T3 and T7 RNA polymerase (Stratagene). The vector was linearized with BamH1 restriction endonuclease (Promega) and with EcoRV restriction endonuclease (Promega) for the construction of antisense and sense cRNA, respectively. In certain experiments, the radiolabeled full length NMDAR-L CRNA was digested into fragments $150-200$ bases long by incubation in alkaline hydrolysis buffer $(40 \mathrm{mM} \mathrm{NaHCO} / 60 \mathrm{mM}$ $\mathrm{Na}_{2} \mathrm{CO}_{3}, \mathrm{pH}$ 10.2). The specificity of hybridization was checked by hybridizing control slides with an NMDAR-L cRNA sense probe. A parallel series of sections of early postnatal and adult brains was hybridized with a ${ }^{33} \mathrm{P}$-labeled cRNA probe complementary to a $300 \mathrm{bp}$ cDNA fragment of the $\alpha 5$ subunit of the GABA $A_{A}$ receptor (Huntsman et al., 1994), serving as a positive control. This probe had a similar specific activity and G/C ratio to the NMDAR-L probe (not illustrated).

Serial sections $(20 \mu \mathrm{m})$ were cut on a freezing microtome, collected in chilled $4 \%$ paraformaldehyde $/ 0.1 \mathrm{M}$ phosphate buffer for a period of $5 \mathrm{hr}$, mounted on Vectabond (Vector Labs) coated slides, and then airdried for $24 \mathrm{hr}$. Sections were lipid extracted in chloroform/ethanol (1: 1) overnight and rehydrated sequentially in $100 \%, 95 \%, 80 \%$, and $70 \%$ ethanol. Sections were washed twice in $0.1 \mathrm{M}$ glycine $/ 0.1 \mathrm{~m}$ phosphate buffer $(3 \mathrm{~min}$ each), in $0.1 \mathrm{M}$ phosphate buffer alone $(15 \mathrm{~min})$, then treated with proteinase $\mathrm{K}\left(2 \mu \mathrm{g} / \mathrm{ml}, 30 \mathrm{~min}, 37^{\circ} \mathrm{C}, \mathrm{pH} 8.0\right)$, incubated in $0.25 \%$ acetic anhydride $/ 0.1 \mathrm{M}$ triethanolamine $(10 \mathrm{~min})$, and finally washed twice in $2 \times \mathrm{SSC}$ (sodium thiosulfate, $0.16 \mathrm{gm} / 100 \mathrm{ml}$ ). Sections were air-dried, and $1 \mathrm{ml}$ hybridization buffer was pipetted onto the slides (composition of the hybridization buffer: $50 \%$ deionized formamide, $10 \%$ dextran sulfate, $0.7 \%$ Ficoll, $0.7 \%$ polyvinyl pyrolidone, 10 $\mathrm{mg} / \mathrm{ml}$ bovine serum albumin, $0.35 \mathrm{mg} / \mathrm{ml}$ denatured herring sperm, $0.12 \mathrm{mg} / \mathrm{ml}$ yeast $\mathrm{t}-\mathrm{RNA}, 40 \mathrm{~mm}$ dithiothreitol, and 10,000 or 15,000 $\mathrm{cpm} / \mu \mathrm{l}{ }^{33} \mathrm{P}$-labeled riboprobe). A coverslip was placed over the drop of fluid and sealed with rubber cement before the slides were incubated at $60^{\circ} \mathrm{C}$ for $48 \mathrm{hr}$ in a moist chamber. At the end of the hybridization, the coverslips were removed, sections were washed twice (in $4 \times \mathrm{SSC}$ at $60^{\circ} \mathrm{C}$ ), and treated with $20 \mu \mathrm{g} / \mathrm{ml}$ ribonuclease $\mathrm{A}\left(30 \mathrm{~min}, 45^{\circ} \mathrm{C}, \mathrm{pH}\right.$ 8.0). The ribonuclease-treated slides underwent a serics of $30 \mathrm{~min}$ washes (twice in $2 \times \mathrm{SSC}$ at room temperature, followed by two washes each in $0.5 \times \mathrm{SSC}$ and $0.1 \times \mathrm{SSC}$ at $60^{\circ} \mathrm{C}$, and a final wash in $0.1 \times \mathrm{SSC}$ at room temperature). The slides were then briefly rinsed in $\mathrm{H}_{2} \mathrm{O}$, airdried, and exposed to Beta Max film (Amersham) for 5-6 d at $4^{\circ} \mathrm{C}$. After development of the film, sections were dipped in Kodak NTB-2 emulsion, and exposed for $21-28 \mathrm{~d}$ at $4^{\circ} \mathrm{C}$. The sections were stained with cresyl violet following development and fixation.

Expression of NMDA receptor subunits in Xenopus oocytes. Xenopus oocytes (stages V-VI) were isolated, enzymatically defolliculated, and injected with $10-50 \mathrm{ng}$ of cRNA $(0.1-1 \mu \mathrm{g} / \mu \mathrm{l})$ that was transcribed from the cDNA clones using the Message Machine Kit from Ambion. Agarose gel electrophoresis was used to confirm that full-length transcripts were obtained. The cRNA concentration was subsequently determined spectrophotometrically by measuring the absorption of a sample aliquot at $260 \mathrm{~nm}$. Electrophysiological measurements were performed in frog Ringer's solution ( $95 \mathrm{mM} \mathrm{NaCl}, 2 \mathrm{mM} \mathrm{KCl}, 2 \mathrm{mM} \mathrm{CaCl}_{2}$, and 5 mM HEPES, pH 7.5) under conventional two microelectrode voltage clamp, generally $2 \mathrm{~d}$ after cRNA injection (Sullivan et al., 1994). In some experiments, $\mathrm{Ca}^{2+}$ was replaced by $\mathrm{Ba}^{2+}(1$ or $20 \mathrm{mM})$ to suppress the $\mathrm{Ca}^{2+}$-activated chloride currents of oocytes. To prevent a possible inhibitory effect on translation of the GC-rich 5 ' untranslated region (UTR) of NMDAR-L (Ishii et al., 1993), a construct (pBS-C4T3) was engineered for expression that contained only the NMDAR-L coding region. Other recombinant NMDA receptor subunits that were co-expressed with the NMDAR-L clone (see Results) were generously provided by the laboratories of Drs. S. F. Heinemann, M. Mishina, N. Nakanishi, and P. Seeburg.

For immunodetection of NMDAR1, oocytes were collected in homogenization buffer $(50 \mu \mathrm{l} /$ oocyte; composition: $100 \mathrm{mM} \mathrm{NaCl}, 20 \mathrm{mM}$ Tris- $\mathrm{HCl} \mathrm{pH} 7.4,1 \%$ Triton $\mathrm{X}-100,170 \mu \mathrm{g} / \mathrm{ml}$ phenylmethanesulfonyl 
fluoride (PMSF), $2.5 \mu \mathrm{g} / \mathrm{ml}$ pepstatin, $2.5 \mu \mathrm{g} / \mathrm{ml}$ leupeptin, $20 \mu \mathrm{g} / \mathrm{ml}$ aprotinin, $20 \mu \mathrm{g} / \mathrm{ml}$ benzamidine- $\mathrm{HCl}$ ), and homogenized in a $15 \mathrm{ml}$ Dounce homogenizer (20 strokes, $1200 \mathrm{rpm}$ ) in a $4^{\circ} \mathrm{C}$ cold room. Homogenates were centrifuged at $1000 \times \mathrm{g}$ for $5 \mathrm{~min}$ at $4^{\circ} \mathrm{C}$, the supernatant was collected. The pellet was resuspended in $1 / 2$ vol fresh homogenization buffer and repelleted. The supernatants were pooled and centrifuged at $100,000 \times \mathrm{g}$ for $90 \mathrm{~min}$ at $4^{\circ} \mathrm{C}$. The pellet was resuspended in RIPA buffer $(5 \mu \mathrm{l} /$ oocyte; composition: $150 \mathrm{~mm} \mathrm{NaCl}, 1 \%$ Nonidet $\mathrm{P}-40,0.5 \%$ deoxycholate, $0.1 \%$ sodium dodecyl sulfate (SDS), $50 \mathrm{~mm}$ Tris pH 7.6, $1 \mathrm{~mm}$ EDTA, $1 \mathrm{~mm}$ EGTA) for subsequent immunoprecipitation and gel electrophoresis (Brose et al., 1994; Sheng et al., 1994).

Culture, transfection, and harvest of the human embryonic kidney cell line (HEK) 293. HEK 293 cells were plated on $100 \mathrm{~mm}$ diameter culture dishes and cultured in minimum essential medium (Sigma), supplemented with $10 \%$ fetal bovine serum (Sigma) and $0.5 \%$ penicillin/streptomycin (Sigma). The cell cultures were incubated at $37^{\circ} \mathrm{C}$ in a humidified atmosphere of $5 \% \mathrm{CO}_{2}$ in air. Nearly confluent HEK 293 cells were transfected in $100 \mathrm{~mm}$ culture dishes with $10 \mu \mathrm{g}$ DNA/subunit using calcium phosphate precipitation. Fresh media were added $24 \mathrm{hr}$ after transfection. Forty-eight hours after transfection, the media were replaced with phosphate-buffered saline (PBS), and the cells were scraped from the plates with a cell scraper. The cell suspension was transferred to a $15 \mathrm{ml}$ conical tube and pelleted by centrifugation at $4^{\circ} \mathrm{C}$ at $800 \times g$ for $3 \mathrm{~min}$. The cells were washed twice in PBS and transferred into a $1.5 \mathrm{ml}$ microcentrifuge tube. Cells were pelleted and resuspended in $50 \mu \mathrm{l}$ of suspension buffer (composition: $0.1 \mathrm{M} \mathrm{NaCl}$, $0.01 \mathrm{~m}$ Tris pH 7.6, $1 \mathrm{~mm}$ EDTA pH 8.0, $2 \mu \mathrm{g} / \mathrm{ml}$ leupeptin, $100 \mu \mathrm{g} / \mathrm{ml}$ PMSF). The cell suspension was subjected to three freeze-thaw cycles (liquid nitrogen $-37^{\circ} \mathrm{C}$ ) and homogenized with a motorized microhomogenizer. The nuclear fraction was then pelleted by centrifugation $\left(16,000 \times g\right.$ for $5 \mathrm{~min}$ at $\left.4^{\circ} \mathrm{C}\right)$, and the remaining supernatant was transferred to a new tube and subsequently used for gel electrophoresis (SDS-PAGE) or immunoprecipitation.

The NMDAR1, NMDAR2B and NMDAR-L subunits used for HEK 293 cell transfections were subcloned into the mammalian expression vectors pcDNA/Neo (Stratagene), pCIS (Genentech), and pBK (Stratagene), respectively (Sucher et al., 1993).

Immunoprecipitation, gel electrophoresis, and immunoblotting. Proteins from HEK 293 cells or Xenopus oocytes were solubilized in RIPA buffer $(500 \mu \mathrm{l}, 2 \mathrm{mg} / \mathrm{ml}$ protein) and precleared with protein A Sepharose $(40 \mu \mathrm{l}$ of $1: 1$ slurry in RIPA, Pharmacia) by rocking for $1 \mathrm{hr}$ at $4^{\circ} \mathrm{C}$, followed by centrifugation for $3 \mathrm{~min}$ at $16,000 \times \mathrm{g}$. Primary antibody $(5 \mu \mathrm{g})$ was subsequently added to the supernatant and incubated at $4^{\circ} \mathrm{C}$ for $90 \mathrm{~min}$. Protein A Sepharose (30 $\left.\mu \mathrm{l}, 1: 1 \mathrm{RIPA}\right)$ was then added and incubated at $4^{\circ} \mathrm{C}$ for $90 \mathrm{~min}$ on a rocker. Finally, the Sepharose was pelleted by centrifugation for $3 \mathrm{~min}$ at $16,000 \times g$, washed four times with RIPA, and resuspended in $30 \mu \mathrm{l}$ of Tris-glycine SDS loading buffer (Novex) supplemented with $1 \mathrm{M}$ urea, $300 \mathrm{mM}$ dithiotreitol, and $1 \mathrm{mM}$ PMSF. SDS-PAGE was performed as described previously using 5.5 (l) $\times 8.5$ (w) cm mini gels (Sucher et al., 1993). Transfer of proteins to PVDF (polyvinylidene difluoride: Millipore, Bedford, MA) membranes and Western blotting with a monoclonal NMDARl antibody was performed as previously detailed (Sucher et al., 1993).

\section{Results}

\section{$P C R$ of a novel NMDA receptor-like subunit}

Degenerate primers were used in PCR experiments in order to isolate previously undiscovered glutamate receptor subunits from the rodent CNS. The downstream (antisense) primer was designed to target a peptide sequence (YTANLAAF) found in both NMDA and non-NMDA receptors (Monyer et al., 1992; Ishii et al., 1993). For the upstream (sense) primer a peptide sequence motif containing two vicinal cysteines (CCYGFCID) was chosen. This motif was originally predicted to be present in NMDA but not non-NMDA receptors based on the finding that only NMDA receptors were susceptible to redox modulation (Aizenman et al., 1989; Sucher et al., 1990; Köhr et al., 1994; Sullivan et al., 1994). All known NMDA receptor subunits share this sequence motif which, in contrast, is absent in all nonNMDA receptor subunits cloned thus far.
The degenerate primers were used with cDNA from early postnatal rodent retina, brain, and the pheochromocytoma cell line, PC12. The PCR products were subcloned, and 40 individual clones were analyzed by DNA sequencing. Sequencing revealed that in addition to all of the known NMDA receptor subunits, one subclone (\#143) derived from retinal cDNA encoded a possible novel NMDA receptor subunit. No PCR products corresponding to the known non-NMDA receptors were found. Using subclone \#143 as a probe, a rat forebrain cDNA library was screened. The nucleotide sequence of one of the clones isolated (clone 4) had a large open-reading frame of 3345 base pairs, the only frame without multiple termination codons. The nucleotide sequence surrounding the initiation codon, particularly position -3 , agreed with the Kozak consensus sequence (Kozak, 1991). The predicted clone 4 polypeptide consisted of 1115 amino acids (Fig. 1), with a calculated molecular mass of 124,494 $\left(M_{r} 124.5\right.$ $\mathrm{kDa}$ ). At the amino acid level, clone 4 shares $\sim 27 \%$ identity with NMDAR1, $\sim 27 \%$ with the NMDAR2 family, and $\sim 24 \%$ with the non-NMDA glutamate receptor subunits. Comparison and alignment of the predicted amino acid sequence of clone 4 with 16 subunits of the ionotropic EAA receptor family that have been cloned in the rat indicate that this novel cDNA clone is most closely related to NMDA receptor subunits with the greatest homology to NMDAR1 (data not shown; see Materials and Methods for details). Clone 4 was therefore designated in a preliminary manner as an NMDA receptor-like subunit (NMDAR-L). It is noteworthy that the grouping of the EAA receptor subunits based solely on the comparison of the predicted amino acid sequences parallels functional and pharmacological classifications.

Hydropathy analysis of NMDAR-L predicted one hydrophobic segment at the $\mathrm{N}$-terminus and four regions of hydrophobicity in the $\mathrm{C}$-terminal half of the amino acid sequence. Comparing amino acid homology, the C-terminal hydrophobic regions aligned specifically with the putative membrane regions $\mathrm{Ml}-4$ of the other glutamate receptor subunits. When the putative M2 region of NMDAR-L (Fig. 1) was aligned with that of the other glutamate receptors, an arginine ( $R$ ) was found adjacent to the so-called "Q/N/R" (glutamine/asparagine/arginine) site while a glycine was located at this site (Sommer et al., 1991; Burnashev et al., 1992; Sakurada et al., 1993). The non-NMDA receptor subunits GluR2, GluR5, and GluR6 are subject to RNA editing at this site resulting in the switch from glutamine (Q) to arginine (R). Channels containing such an edited subunit are characterized by their very low $\mathrm{Ca}^{2+}$ permeability (Sommer et al., 1991). Site -directed mutagenesis experiments indicated that the $Q / N / R$ site also influences the divalent ion permeability and the $\mathrm{Mg}^{2+}$ block of recombinant NMDA receptors (Burnashev et al., 1992; Kawajiri and Dingledine, 1993; Sakurada et al., 1993). These findings raised the possibility that NMDAR- $L$ may produce a low permeability to divalent cations (see below).

Scanning of the NMDAR-L amino acid sequence with motifs in the Prosite database revealed multiple potential sites for $\mathrm{N}$-glycosylation, N-myristoylation, and phosphorylation by several protein kinases, including protein kinase $\mathrm{C}$, and tyrosine kinase (Fig. 1)

\section{Developmental and regional expression pattern of NMDAR- $L$} $m R N A$

Northern blot analysis of rat brain at postnatal days 3, 8, 12, and adult indicated that the expression of NMDAR-L mRNA is high in the first two weeks after birth, but subsequently decreases, 
NMDAR-L MRRLSLWWLL SRVCLLLPPP CALVLAGVPS SSSHPQPCQI LKRIGHAVRV GAVHLQPWTT APRAASRAQE

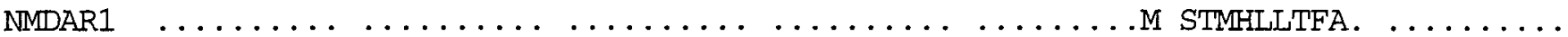

NMDAR-L GGRAGAQRDD PESGTWRPPA PSQGARWLGS ALHGRGPPGS RKLGEGAGAE TLWPRDALLF AVENLNRVEG

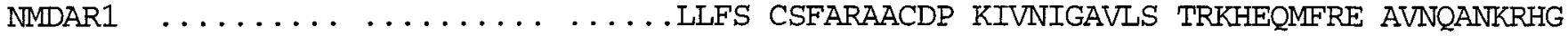

NMDAR-L LLPYNLSLEV VMAIEAGLGD LPLMPFSSPS SPWSSDPFSF LQSVCHTVVV QGVSALIAFP QNQGEMMELD NMDAR1 SWKIQLNATS VTHKPNAIQ. ...MALSVCE DLISSQVYAI LVSHPPT... ....... NDHFTPTPVS

NMDAR-L LVSSVLHIPV LSIVRHEFPR ESQNPLHLQ. LSLENSLSSD ADVTVSILTM NNWYNFSLLI C. . QEDWNIT NMDAR1 YTAGFYRIPV LGLTTR.MSI YSDKSIHLSF LRTVPPYSHQ SSVWFEMMRV YNWIHIILLV SDDHEGRAAQ

NMDAR-L DFL. .LLTEN NSKFHLESVI NITANLSSTK DLLSFLQVQM DNIRNSTPTM VMFGCDMDSI RQIFEMSTQF NMDAR1 KRLETLLEER ESK. .AEKVL QFDP...GTK NVTALIM... . EARELEARV IILSASEDDA ATVYRAAAML

NMDAR-L GLSPPELHWV LGDSQNVEEL RTEGL...PL GLIAHGKTTQ SVFEYYVQDA MELVARAVAT ATMIQPELAL NMDAR1 NMTGSGYVWL VGER. ....EI SGNALRYAPD GIIGLQLING KNESAHISDA VGVVAQAV. . HELLEKE. NI

NMDAR-L LPSTMNCMDV KTTNLTSGQY LSRFLANTTF RGLSGSIKVT GSTIISSENN FFIWINLHDP MGKPMWTRLG NMDAR1 TDPPRGCVG. NTNIWKTGPL FKRVLMSSKY AD. . . . GVT GRVEFNEDGD RKFANYSIMN LQNRKLVQVG

NMDAR-L SWQGGRTVMD .. SGIWPEQA QRHKTHFQHP NKLHLRVVTL IEHPFVFTRE VDDEGLCPAG QLCLDPMTND NMDARI IYNGTHVIPN DRKIIWPGGE TEKPRGYQMS TR. .LKIVTI HQEPFVYVKP TMSDGTCK.. ....EEFTVN

NMDAR-I SSMLDRLFS. . . . . SLHSS NDTVPIKFKK CCYGYCIDLL EQLAEDMNFD FDLYIVGDGK YGALENGH.. NMDAR1 GDPVKKVICT GPNDTSPGSP RHTVP....Q CCYGFCIDLL IKLARTMNFT YEVHLVADGK FGTQERVNNS

NMDAR-L ....WTGLVG DLLSGTANMA VTSFSINTAR SQVIDFTSPF FSTSLGILVR TRDTAAPIGA FMWPLHWTMN NMDAR1 NKKEWNGMMG ELLSGQADMI VAPLTINNER AQYIEFSKPF KYQGLTILVK KEIPRSTLDS FMQPFQSTLW M 1 M 2

NMDAR-L LGIFVALHIT AIFLTLYEWK SPFG. .MTPK GRNRNKVFSF SSAINVCYAL LFGRTAAIKP PKCWTGRFLM NMDAR1 LLVGLSVHVV AVMLYLLDRF SPFGRFKVNS EEEEEDALTL SSAMWFSWGV LINSGIGEGA PRSFSARILG M 3

NMDAR-L NLWAIFCMFC LSTYTANLAA VMVGEKIYEE LSGIHDPKLH HPSQGFRFGT VRESSAEDYV RQ. . SFPEMH NMDAR1 MUWAGFAMII VASYTANLAA FLVLDRPEER ITGINDPRLR NPSDKFIYAT VKQSSVDIYF RRQVELSTMY

NMDAR-L EYMRRYNVPA TPDGAQYLKN DPEKLDAFIM DKALLDYEVS IDADCKLLTV GKPFAIEGYG IGLPPNSPLT NMDAR1 RHMEKHNYES AAEAIQAVRD N. KLHAFIW DSAVLEFEAS . QKCDLVIT GELFFRSGFG IGMRKDSPWK NMDAR-L SNISELISQY KSHGFMDVLH DKWYKVVPCG KRSFGATETL QMGIKHFSGL FVLLCIGFGI SILTTIGEHI NMDAR1 QNVSLSILKS HENGFMEDLD KTWVRYQECD SRSNAPAT. . . LTFENMAGV FMLVAGGIVA GIFLIF....

NMDAR-L VHRLLLPRIK NKSKLEDWLD TSQRFHRALN TSFVEEKQPR SKTKRVEKRS NLGPQQLMVW NTSNLSHDNQ

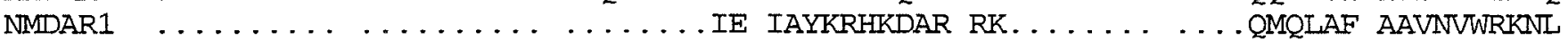

NMDAR-L RKYIFNDEEG QNQLGTQAHQ DIPLPQRRRE LPASLTTNGK ADSLNVTRSS VIQELSELEK QIQVIRQELQ NMDAR1 ........ QDRKSGRAEP D...PKKKKAT FRA. ITSTL ASSFKRRRSS KDTSTGGGRG ALQNQKDTVL

NMDAR-L LAVSRKTELE EYQKTIRTCE S

MMDARI PRRAIEREEG QLQLCSRHRE $S$

Figure 1. The deduced amino acid sequence for NMDAR-L and NMDAR1 (Moriyoshi et al., 1991). The predicted signal peptide (SP) and four membrane regions $(M l-M 4)$ are underlined as well as a possible phosphorylation site for tyrosine kinase.

with virtually undetectable levels in the adult brain (Fig. 2). Northern blots with RNA from P0 and P10 mouse brain showed the same band pattern as that in rat, with virtually undetectable levels in the adult brain (not illustrated). To characterize further the anatomical localization and developmental regulation of NMDAR-L mRNA expression in the rodent brain, in situ hybridization histochemistry was performed in mice. Sections from early postnatal animals that were hybridized with radiolabeled
NMDAR-L antisense cRNA showed specific labeling in particular areas of the forebrain, midbrain, and hindbrain.

In the forebrain of P1 animals, NMDAR-L InRNA expression was most pronounced in the thalamus, the entorhinal cortex, and the subiculum (Fig. 3B,D). In addition, hybridization was detected throughout the entire rostro-caudal extent of layer $\mathrm{V}$ of the developing neocortex (Fig. 3D). There was virtually no hybridization over the striatum or globus pallidus, the ventricular 


\section{P3 P8 P12 Ad}

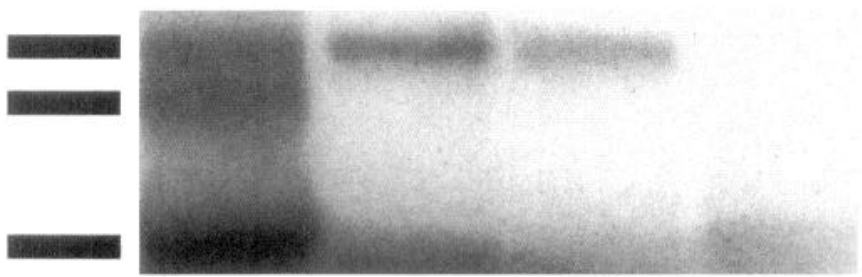

Figure 2. Northern blot analysis of total RNA $(10 \mu \mathrm{g} / \mathrm{lane})$ from rat brains at $\mathrm{P} 3, \mathrm{P} 8, \mathrm{P} 12$, and adult $(A d)$. Note that three bands (black bars at $\sim 8,7$, and $4.0 \mathrm{~kb}$ ) were labeled at $\mathrm{P} 3$, indicating the possible expression of three splice variants of this gene. NMDAR-L transcript levels decrease with increasing age.

zone, the intermediate zone, or the olfactory bulb. No hybridization was observed over the dentate gyrus or the CA fields of the hippocampus (Fig. $3 B$ ). In the midbrain, NMDAR-L mRNA was expressed in the pretectum and in the superior and inferior colliculi. Expression levels were low, however, compared to the thalamus and the entorhinal cortex (Fig. $3 B, D, F$ ). In the hindbrain, NMDAR-L expression was very low. The cerebellum, in particular, did not exhibit detectable levels of hybridization (Fig. $3 F)$.

In the forebrain of P4 and P5 animals, NMDAR-L mRNA expression was again pronounced in layer $\mathrm{V}$ throughout the entire rostro-caudal extent of the neocortex, as well as in the piriform cortex, the entorhinal cortex, the subiculum, and the CA1 field (Figs. $4 B, D, 5 A$ ). Heavy labeling was also observed in the thalamus. In other forebrain areas, such as the olfactory bulb, the dentate gyrus; the $\mathrm{CA} 2, \mathrm{CA} 3$, and CA4 fields; and the striatum and globus pallidus, levels of expression were very low and not clearly distinguishable from background (Fig. $4 B, D, F$ ). In the midbrain, low levels of expression were detected in the superior and inferior colliculi. In other parts of the midbrain and in all parts of the hindbrain, including the cerebellum, levels of expression were very low and indistinguishable from background (Fig. 4D,F).

In the forebrain of P14 animals, high levels of NMDAR-L mRNA were detected in layer $\mathrm{V}$ throughout the rostro-caudal extent of the neocortex, but now with additional expression in layers II, III, IV, and VI (Figs. 6A, $D, F, 7 A$ ). Pronounced hybridization was also present in the piriform cortex, the entorhinal cortex, the subiculum, and the CA1 field. The nucleus of the lateral olfactory tract was also heavily labeled. The intensity of hybridization over the dentate gyrus, the CA2-4 fields, the striatum and globus pallidus, and the olfactory bulb was indistinguishable from background (Fig. $6 A, C, D$ ). Levels of NMDAR-L mRNA in the thalamus were very low except in the zona incerta (Fig. 6D). In all areas of the midbrain and the hindbrain, hy-

Figure 3. $A, C, E$, Nissl stained parasagittal sections from a P1 animal. $B, D$, and $F$, Film autoradiograms of sections adjacent to $A, C$, and $E$, hybridized with NMDAR-L antisense cRNA, showing expression patterns. Note high levels in entorhinal cortex, subiculum, and thalamus. $C B$, Cerebellum; $D$, dentate gyrus; $E$, entorhinal cortex; $F$, frontal region of the cortical plate; $I C$, inferior colliculi; $M$, medulla; $O$, olfactory bulb; $P$, piriform cortex; $P N$, pontine nuclei; $S$, future somatosensory area of the cortical plate; $S C$, superior colliculi; $S T$, striatum; $S U$, subiculum; $T$, thalamus; $V$, future visual area of the cortical plate; $V Z$, ventricular zone. Scale bars, $1 \mathrm{~mm}$.

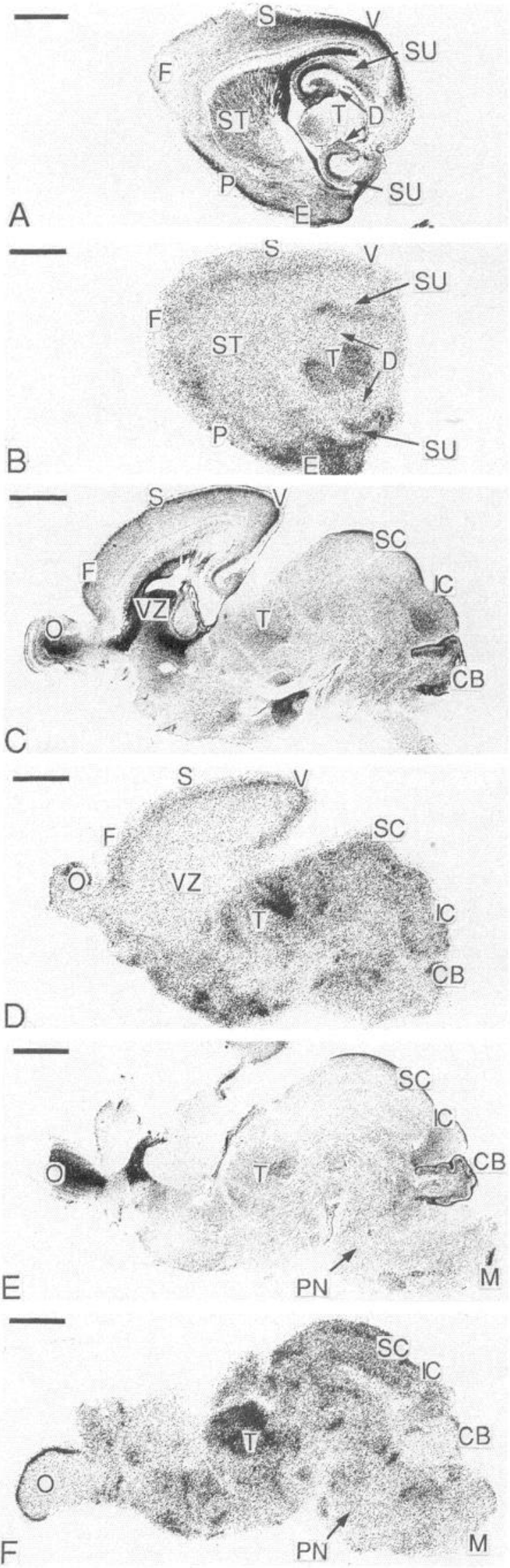




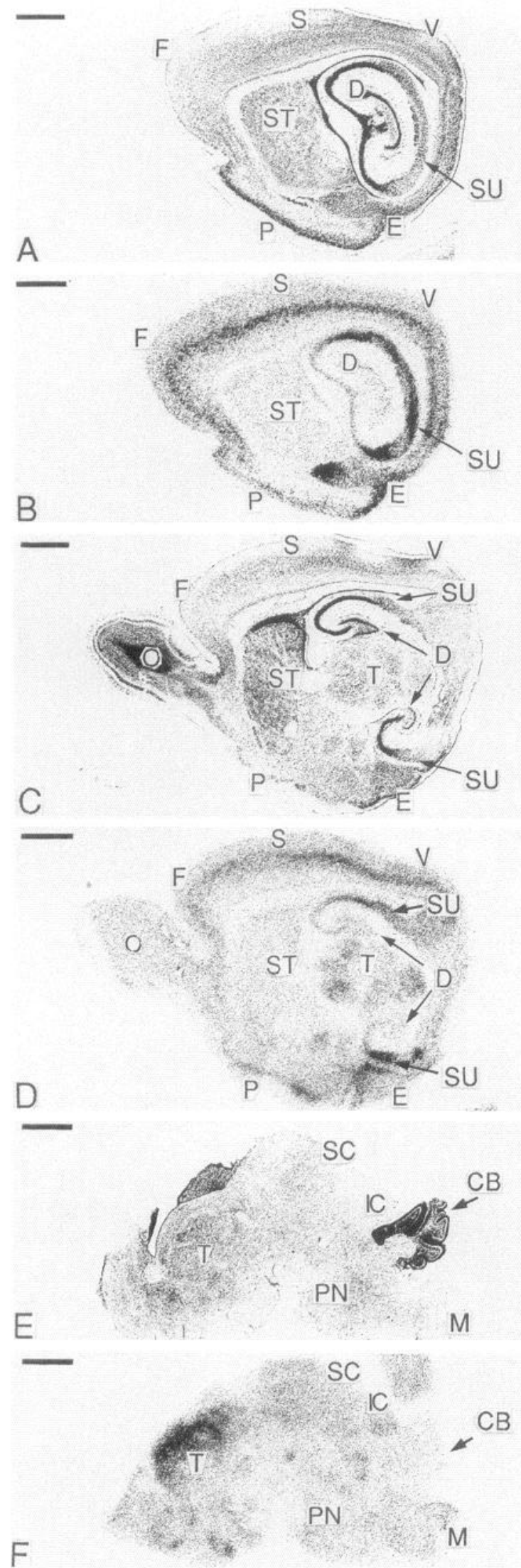

Figure 4. $A, C$, and $E$, Nissl stained parasagittal sections from a P5 animal. $B, D$, and $F$, Film autoradiograms of sections adjacent to $A, C$, and $E$, hybridized with NMDAR-L antisense cRNA. Note increased levels of hybridization in layer V of the cerebral cortex. For abbreviations, see Figure 5 caption. Scale bars, $1 \mathrm{~mm}$.

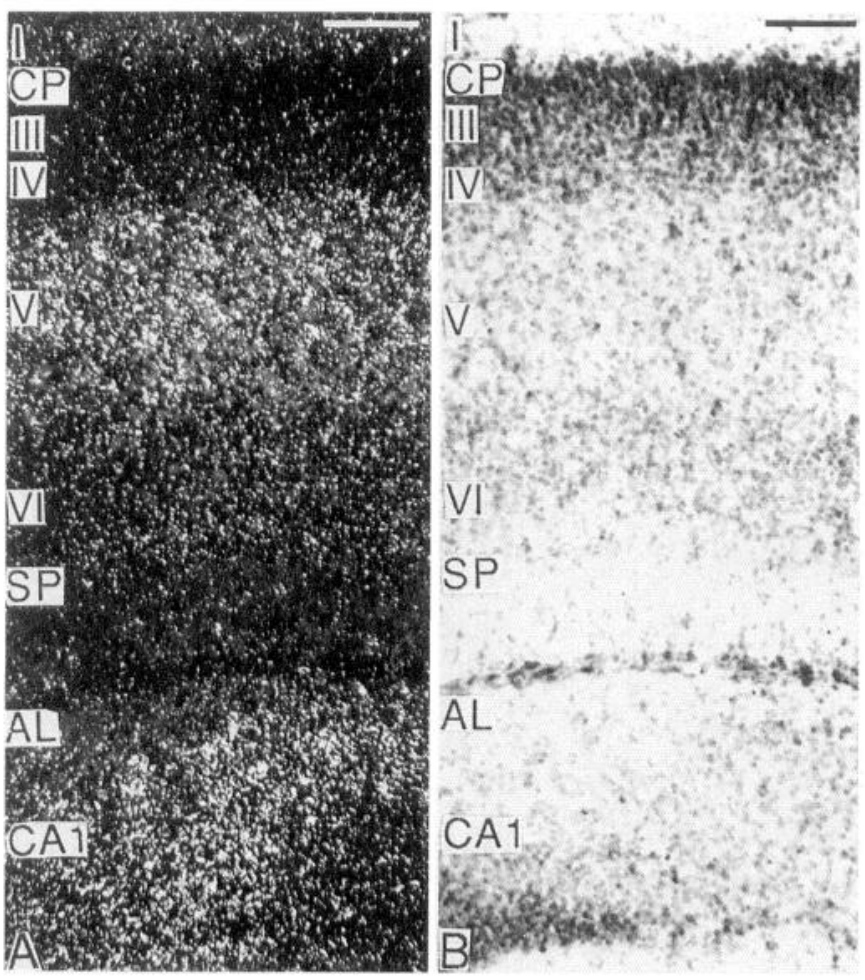

Figure 5. A, Dark-field photomicrograph of an emulsion-dipped section from a P4 animal, hybridized with antisense NMDAR-L cRNA. This section shows hybridization in layer $\mathrm{V}$ of the visual cortex, in the CA1 field, and in the subiculum. $B$, Bright-field photomicrograph of the same field shown in $A$. $A L$, Alveus; $C A 1$, CA1 field; $C P$, cortical plate; $S P$, subplate, I, III, IV, V, and VI indicate cortical layers. Scale bars, $100 \mu \mathrm{m}$.

bridization signals were very weak (Fig. $6 F$ ) and similar in intensity to signals obtained on sections that were hybridized with sense control probes (Fig. 6C).

In the forebrain of adult animals, pronounced expression of NMDAR-L mRNA was found in the nucleus of the lateral olfactory tract (Fig. $8 F$ ). However, in all other areas of the forebrain, the intensity of hybridization was very low (Fig. $8 B, D$ ), comparable to the intensity obtained in hybridization experiments with sense control probes (Fig. 9). In the midbrain and in the hindbrain, levels of hybridization were also very low and indistinguishable from background (Figs. $8 B, D, F, 9$ ).

Compared with hybridization experiments using full length cRNA antisense probes, no difference in the labeling pattern or in the signal-to-noise ratio was observed in sections that were hybridized with radiolabeled cRNA that had been subjected to alkaline hydrolysis. Sections hybridized with a lower probe concentration $(10,000 \mathrm{cpm} / \mu \mathrm{l})$ showed the same labeling pattern and signal-to-noise ratio compared to sections hybridized with a higher concentration $(15,000 \mathrm{cpm} / \mu \mathrm{l})$.

\section{Cellular expression pattern of NMDAR-L mRNA}

In emulsion dipped sections that were hybridized with NMDAR-L antisense cRNA, discrete grain clusters were observed over numerous cells, most of them having a diameter larger than $12 \mu \mathrm{m}$. Therefore, these cells are likely to be neurons. No grain clusters were found in cells with a diameter smaller than $8 \mu \mathrm{m}$, suggesting that neuroglial cells do not express NMDAR-L mRNA. Staining in the neuropil was very low 


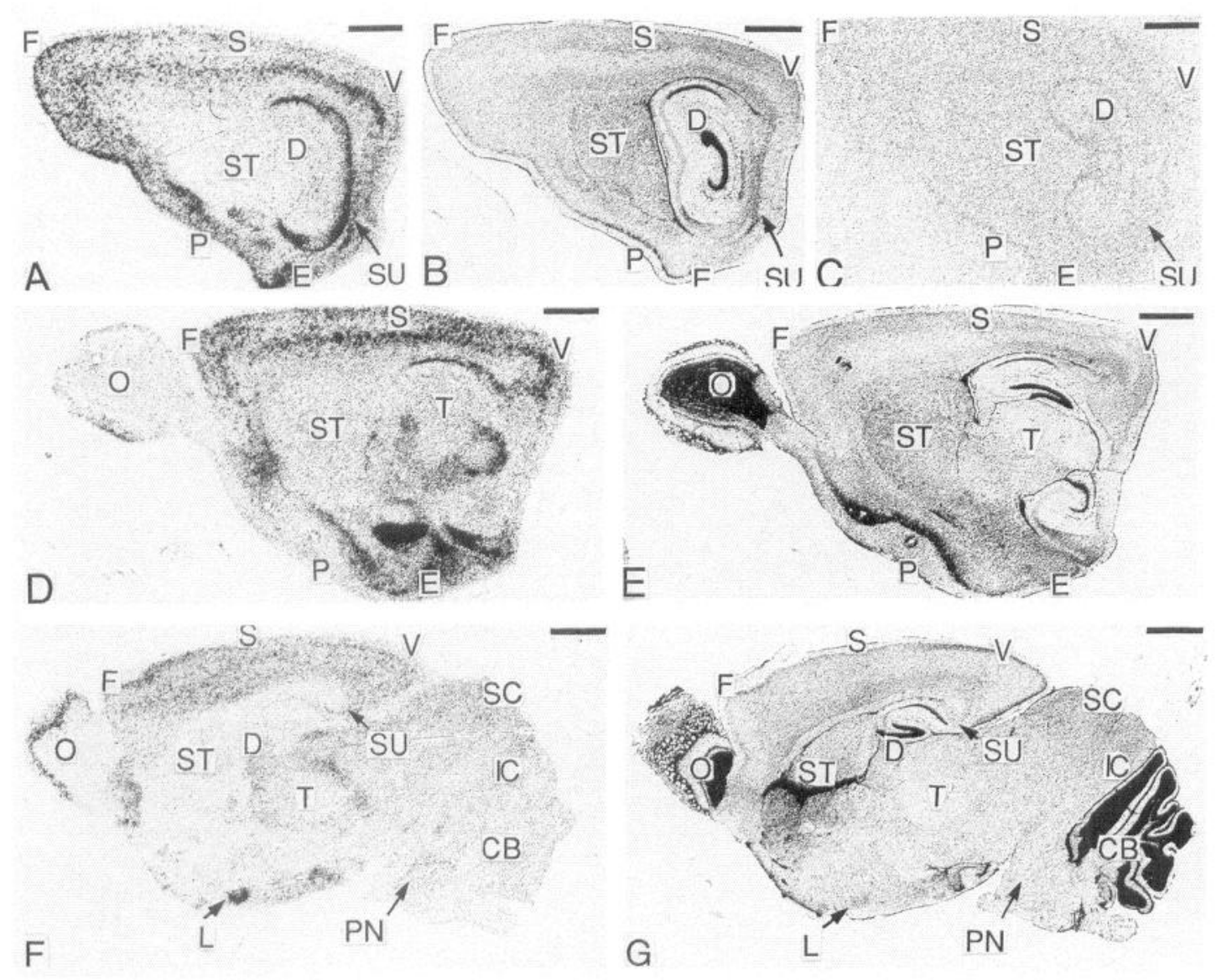

Figure 6. $A, D$, and $F$, Film autoradiograms of parasagittal sections from a P14 animal, hybridized with antisense NMDAR-L cRNA, showing continued high levels in entorhinal cortex and in layer $\mathrm{V}$ of neocortex. $B, E$, and $G$, Nissl stained sections adjacent to $A, D$, and $F$. $C$, Film autoradiogram of a section adjacent to $A$ and hybridized with sense NMDAR-L cRNA. $F$, Frontal cortex; $L$, nucleus of the lateral olfactory tract; $S$, somatosensory cortex; $V$, visual cortex; for other abbreviations, see Figure 5 caption. Scale bars, $1 \mathrm{~mm}$.

and was indistinguishable in intensity from sections that were hybridized with sense control probes.

\section{Expression of NMDAR-L cRNA in Xenopus oocytes}

Hydropathy analysis of the amino acid sequence predicted four regions of hydrophobicity that aligned with the putative membrane regions of other ionotropic glutamate receptor subunits. Therefore, the Xenopus oocyte expression system was used to investigate whether NMDAR-L cRNA might form functional glutamate-activated ion channels. To date, however, no glutamate-activated membrane currents have been detected when NMDAR-L cRNA (10-50 ng) was injected into oocytes.

Based on the close homology of NMDAR-L with the NMDA receptor subunits, especially with NMDAR1, the effect of coinjection of NMDAR-L with one of the NMDAR2 subunits (NR2AD) was also investigated. However, coinjection of NMDAR-L cRNA with each of the NMDAR2 cRNAs did not lead to the expression of glutamate or NMDA-activated currents, even in the absence of external $\mathrm{Mg}^{2+}$ and in the presence of $10 \mu \mathrm{M}$ glycine. Coinjection of NMDAR-L and NMDAR1 cRNAs did not result in NMDA-evoked currents larger than those observed with NMDAR1 alone.

When the putative M2 region for the NMDAR-L subunit was aligned with that of the other glutamate receptors, an arginine (R) was found adjacent to the " $\mathrm{Q} / \mathrm{N} / \mathrm{R}$ " (glutamine/asparagine/ arginine) site. By analogy to studies on NMDAR1 mutants at the "Q/N/R" site, this would be predicted to reduce the $\mathrm{Mg}^{2+}$ block and diminish the divalent ion permeability of the receptor (Burnashev et al., 1992; Kawajiri and Dingledine, 1993; Sakurada et al., 1993). Therefore, site-directed mutagenesis was used in order to change the arginine in position 730 into an asparagine, resulting in the mutant NMDAR-L/R730N. The mutation was verified by DNA sequencing. Like wild-type NMDAR-L, however, injection of NMDAR-L/R730N cRNA, either alone or in conjunction with NMDAR1 or NMDAR2B, did not lead to expression of functional glutamate-gated ion channels.

However, a consistent electrophysiological effect of NMDAR-L cRNA was observed when it was co-injected with either NMDAR1 or NMDAR1 plus NMDAR2 cRNAs. For example, when NMDAR-L cRNA was coinjected into oocytes with NMDAR1 (double combination) or with NMDAR1 plus NMDAR2B cRNA (triple combination), a marked reduction was noticed in the resulting NMDA-induced currents compared to oocytes from the same batch that had been injected with either NMDAR1 alone or NMDAR1 plus NMDAR2B. This effect was quantified by comparing NMDA-induced currents injected with either a combination of NMDAR1 plus NMDAR2B or NMDAR1, NMDAR2B, plus NMDAR-L (Table 1). The NMDAR1/NMDRA2B combination was chosen because it routinely gave robust NMDA-induced currents in our hands. Coinjection of NMDAR-L dramatically reduced the NMDA-induced currents in both $\mathrm{Ba}^{2+}(2$ or $20 \mathrm{~mm})$ or $\mathrm{Ca}^{2+}(2 \mathrm{mM})$ containing extracellular solutions. 


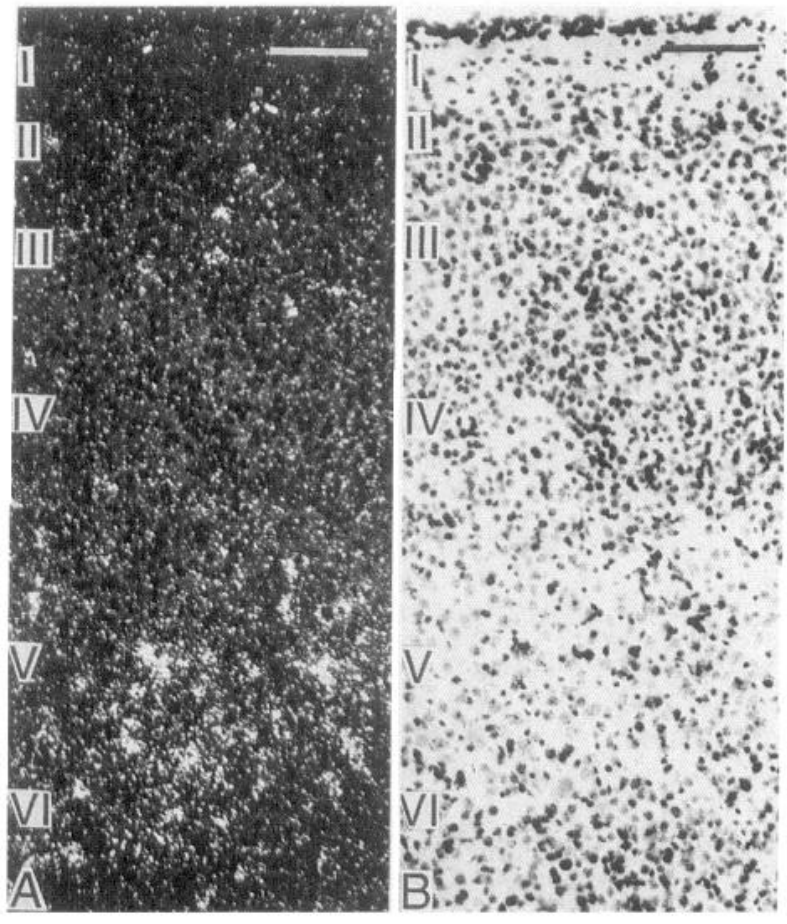

Figure 7. A, Dark-field photomicrograph through the full vertical thickness of the somatosensory (barrel) cortex of an emulsion-dipped section hybridized with NMDAR-L antisense cRNA, showing hybridization to cells located in lower layer V at P14. B, Bright-field photomicrograph of the same field shown in $A$. $I-V I$ indicate cortical layers. Scale bars, $100 \mu \mathrm{m}$.

Coinjection of the mutant NMDAR-L/R730N with NMDAR1 plus NMDAR2B had a similar inhibitory effect. The NMDAinduced currents were in all cases blocked by $0.5 \mathrm{~mm} \mathrm{Mg}{ }^{2+}$ at $-60 \mathrm{mV}$ with no apparent change in the $I / V$ curve (data not shown). The observed reduction in current did not appear to be caused by a change in the dose-response curves of either agonists NMDA and glutamate or coagonist glycine (not illustrated). In parallel experiments, no reduction in NMDA-evoked current was observed when NMDAR1 and NMDAR2B were coinjected with cRNA corresponding to the "orphan" glutamate receptor subunit delta 2 (Table 1). The delta 2 subunit shares the lowest sequence homology with the NMDA receptor subunits and, like NMDAR-L, does not form homomeric glutamate-activated ion channels.

It is possible that the observed reduction of the NMDAevoked current by NMDAR-L is due to its incorporation into a receptor/channel complex with altered biophysical properties consisting of all three subunits (Wafford et al., 1993). Alternatively, incorporation of NMDAR-L may render such receptor complexes nonfunctional. However, other mechanisms acting at the level of translation, transport, or assembly of the individual subunits must be considered. Therefore, immunoprecipitation and Western blotting were used in order to investigate whether or not coexpression of NMDAR-L cRNA might interfere with the translation of the essential NMDA receptor subunit NMDAR 1 resulting in reduced expression of functional channels. Membrane protein extracts from batches of oocytes that had been injected with either a double combination of subunits (NMDAR1 plus NMDAR2B) or a triple combination (NMDAR1, NMDAR2B, and NMDAR-L) were used for immunoprecipitation and subsequent Western blotting using a monoclonal NMDAR1 antibody (Sucher et al., 1993; Brose et al., 1994; Sheng et al., 1994). The amount of NMDAR1 protein did not appear to differ significantly between the two groups (Fig. 10A). Since the total amount of NMDAR1 protein in oocytes was very low, HEK 293 cells were used in additional experiments. Again, no reduction in the amount of NMDAR1 protein was detected when HEK 293 cells that had been transfected with either the double or triple combination of subunits were compared (Fig. 10B). These experiments are a first step towards further biochemical characterization of the action of NMDAR-L. The elucidation of the mechanism of NMDA current reduction in the presence of NMDAR-L should be facilitated by the future availability of NMDAR-L specific antibodies.

\section{Discussion}

A cDNA with an open reading frame of 3,345 base pairs was isolated from a rat forebrain library. The predicted amino acid sequence is most closely related to subunits for NMDA receptors. Additional evidence also suggests that NMDAR-L is an NMDA receptor subunit. Firstly, all of the 40 clones independently sequenced in the PCR based strategy for isolating NMDAR-L were either variants of NMDAR-L or of the five already characterized NMDA receptor subunit genes. Secondly, multiple gaps that are created in the computer alignment of the amino acid sequence of NMDAR-L with the other glutamate receptors are shared only by NMDA receptor subunits. Thirdly, NMDAR-L contains vicinal cysteine residues that are homologous to those within the NMDAR1 and NMDAR2 subunits and are unique to the NMDA subclass of glutamate receptors. When these cysteines are mutated in any NMDA receptor subunit to charged residues, receptor activity is abolished (Laube et al., 1993; Sullivan et al., 1994). This suggests that the vicinal cysteines play a specific and critical role in either the NMDA receptor subunits' conformation or assembly. Fourthly, in all nonNMDA glutamate receptors the loop separating the putative M3 and M4 segments is of fixed length and displays very strong amino acid conservation. NMDAR-L, like the NMDAR1 and NMDAR2 subunits, displays no such conservation. Finally, coinjection of NMDAR-L with NMDAR1 and NMDAR2B cRNAs appears to decrease the magnitude of NMDA-evoked currents compared to those seen after coexpression of NMDAR1 with NMDAR2B in the absence of NMDAR-L, suggesting a possible association of NMDAR-L with NMDAR1 and/or NMDAR2B.

The mechanism(s) underlying the observed reduction of the NMDA-induced currents upon coinjection of NMDAR-L, NMDAR1, and NMDAR2B is not yet known. Although it is possible that NMDAR-L is incorporated into a receptor/channel complex with altered biophysical properties consisting of all three subunits (Wafford et al., 1993), we cannot exclude the possibility that receptors containing NMDAR-L are in fact nonfunctional. However, other mechanisms acting at the level of translation, transport, or assembly of the individual subunits must be considered. The immunoblotting experiments indicate, however, that NMDAR-L does not appear to inhibit translation of NMDAR1.

The present study indicates that NMDAR-L mRNA is expressed in many regions of the immature brain, while expression in the adult brain is restricted to the nucleus of the lateral olfactory tract. The expression of the previously described ionotropic glutamate receptor subunits also undergoes changes during brain 

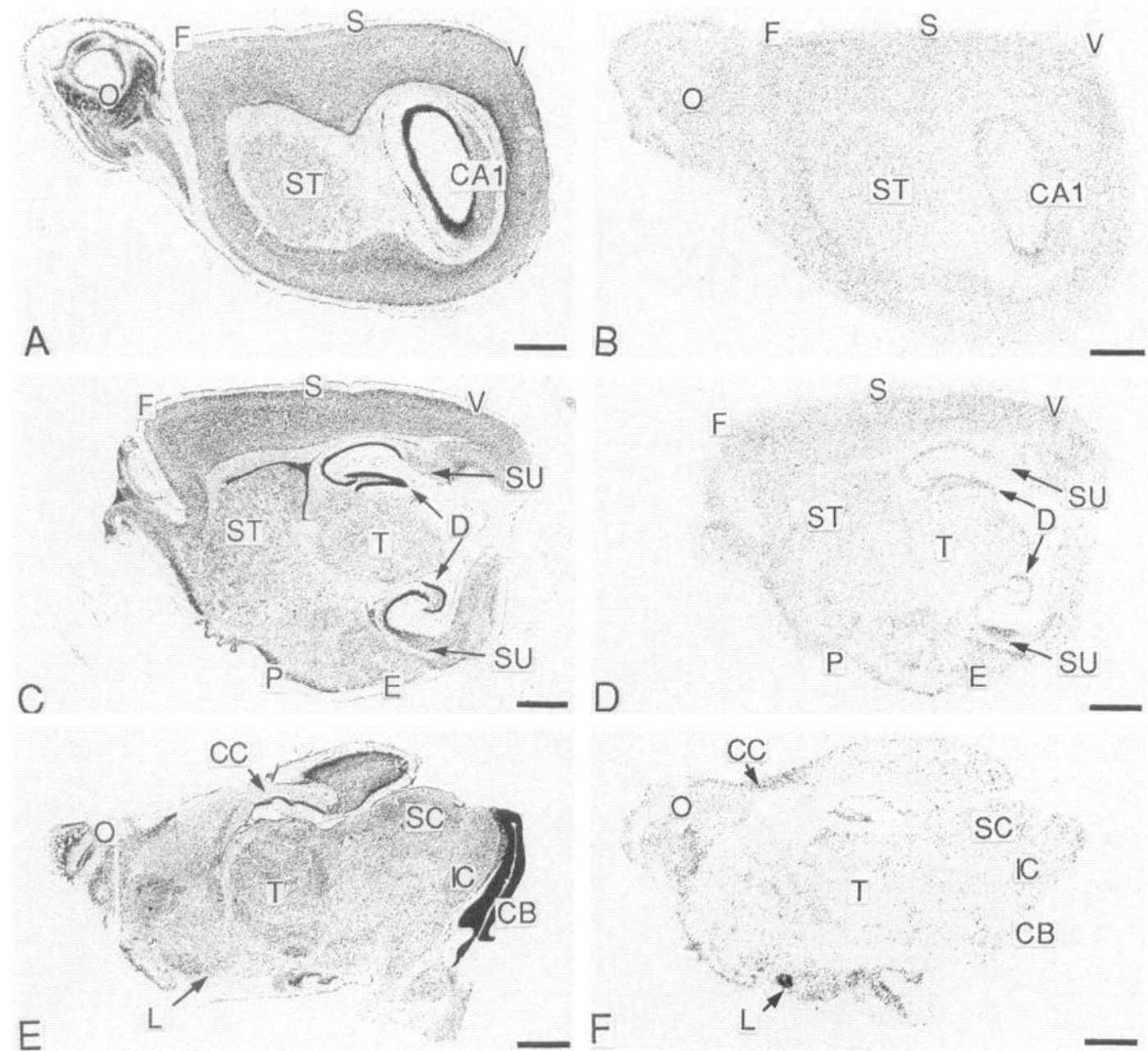

Figure 8. $A, C$, and $E$, Nissl stained parasagittal sections of an adult animal. $B, D$, and $F$, Film autoradiograms of adjacent sections to $A, C$, and $E$, hybridized with antisense NMDAR-L cRNA, showing reduced levels of expression in all areas except nucleus of the lateral olfactory tract $(L)$. $C C$, Corpus callosum; for other abbreviations see captions to Figures 3 and 6 . Scale bars, $1 \mathrm{~mm}$.

development (Hollmann et al., 1989; Boulter et al., 1990; Monyer et al., 1991; Watanabe et al., 1992; Araki et al., 1993; Watanabe et al., 1993; Farrant et al., 1994; Laurie and Seeburg, 1994; Monyer et al., 1994; Sheng et al., 1994). Gene expression of other previously described NMDA receptor subunits peaks

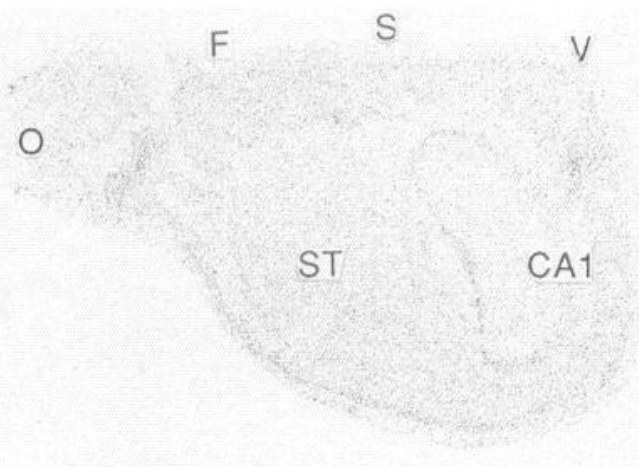

Figure 9. Film autoradiogram of a section adjacent to the sections shown in Figure $4, A$ and $B$, but hybridized with sense NMDAR-L cRNA. There is no labeling above background. For abbreviations see Figure 6 caption. Scale bar, $1 \mathrm{~mm}$. during development and is subsequently downregulated in the mature brain (Monyer et al., 1994). The changes in NMDAR-L expression during the course of development appears to be more dramatic when compared to the regulation of expression of the NMDAR1 and NMDAR2A-D subunits (Monyer et al., 1994).

While the physiological role of NMDAR-L must await future experiments, for example, with "knock-out" mice lacking the NMDAR-L gene product, several conclusions can be drawn from the results of the present study. The NMDAR-L gene product is probably not involved in the process of neuronal migration that is mediated at least in part by NMDA receptor and N-type calcium channel activity (Komuro and Rakic, 1992, 1993). In the rodent brain, the migration period of cortical neurons starts in the last week of the prenatal period and extends into the first 3 or $4 \mathrm{~d}$ of the postnatal period (Berry and Rogers, 1965; Hicks and D'Amato, 1968). Neurons destined for layers V and VI of the developing cerebral cortex reach their targets at the time around birth (Hicks and D'Amato, 1968). The results of the present study indicate that the NMDAR-L gene is not expressed along the pathway of migrating cortical neurons, that is, the ventricular zone, the intermediate zone, the region of the cortical subplate, and in the cortical plate itself (Rakic, 1972; Shatz et al., 1988). In addition, the lack of NMDAR-L expression during 


\begin{tabular}{lllll}
\hline Table 1. & NMDAR-L subunit decreases NMDA-evoked currents in oocytes & \\
& & NMDAR1 + & NMDAR1 + & NMDAR1 + \\
Subunit & NMDAR1 + & NMDAR2B + & NMDAR2B + & NMDAR2B + \\
combination & NMDAR2B & NMDAR-L & NMDAR-L/R730N & Delta 2 \\
\hline $\begin{array}{l}\text { Current } \\
\text { amplitude }\end{array}$ & $300.0 \pm 66.5 \mathrm{nA}$ & $44.0 \pm 9.6 \mathrm{nA}$ & $34.2 \pm 10.2 \mathrm{nA}$ & $274 \pm 87.0 \mathrm{nA}$ \\
& $n=14$ & $n=15$ & $n=7$ & $n=7$ \\
\hline
\end{tabular}

Inward currents under two-electrode voltage clamp were evoked in Xenopus oocytes by application of $200 \mu \mathrm{M}$ NMDA plus $10 \mu \mathrm{M}$ glycine in frog Ringer's solution containing $20 \mathrm{mM} \mathrm{Ba}^{2+}$ with no added $\mathrm{Ca}^{2+}$ or $\mathrm{Mg}^{2+}$. $\mathrm{Holding}$ potential was $-60 \mathrm{mV}$. The numbers represent the mean $\pm \mathrm{SD}$. Oocytes (stages V-VI) were injected with $\sim 30 \mathrm{ng} /$ subunit of cRNA. See Materials and Methods for details.

the entire postnatal period of cerebellar development rules out its involvement in the migration of cerebellar neurons, which is not finished before the end of the second postnatal week (Rakic and Sidman, 1973).

NMDA receptors in the developing brain are thought to be involved in neurite outgrowth and the subsequent formation of connectivity patterns (Shatz, 1990). It is therefore of interest that NMDAR-L gene expression in the developing thalamus is most pronounced in the first $5 \mathrm{~d}$ of postnatal life. This period corresponds to the time when axons of thalamic neurons reach their targets in the cerebral cortex and subsequently refine their connections (Senft and Woolsey, 1991; Agmon et al., 1993, 1995; Schlaggar et al., 1993). It is therefore conceivable that the NMDAR-L gene product is involved in helping establish the orderly pattern of thalamic projections to the cerebral cortex.

Our data show that in the developing neocortex NMDAR-L gene expression is most pronounced in layer V. The entire population of spinal- and brainstem-projection neurons is located in this layer (Wise and Jones, 1977; Koester and O'Leary, 1992), together with a substantial proportion of neurons that send axons to the contralateral cerebral cortex (Wise and Jones, 1976). In the rodent brain, the outgrowth of axons of layer $\mathrm{V}$ neurons starts during the final days of the prenatal period (Schreyer and Jones, 1982; De Carlos and O'Leary, 1992). These axons reach their targets in the mid- and hindbrain in early postnatal life (Stanfield et al., 1982; De Carlos and O'Leary, 1992). However, in the case of axons destined for the caudal segments of the spinal cord, the outgrowth process is not finished before the end of the second postnatal week (Schreyer and Jones, 1982). The subcortical projection pattern of layer $\mathrm{V}$ neurons in the early postnatal period differs profoundly from the pattern that is ob- served in the adult brain. Initially, single axons of layer $\mathrm{V}$ neurons located in all areas of the cerebral cortex form branches and grow towards multiple targets in the brainstem and spinal cord (O'Leary and Koester, 1993). In the mature brain, the subcortical projection patterns of individual cortical areas are much more limited. The elimination of axon branches directed towards inappropriate targets and the remodeling of the connectivity patterns of layer $\mathrm{V}$ neurons in the rodent brain is completed around the end of the second postnatal week (Stanfield et al., 1982; Stanfield and O'Leary, 1985). Therefore, the period of axonal outgrowth and subsequent refinement of the projections of the pyramidal neurons in layer $\mathrm{V}$ coincides with the time when the NMDAR-L gene is expressed heavily in layer $\mathrm{V}$ neurons, suggesting that NMDAR-L gene product may play a role in the establishment of the subcortical projections of these neurons.

During the first two postnatal weeks, the pyramidal projection neurons of layer $\mathrm{V}$ undergo a severalfold increase in somal volume and a substantial increase in number of primary dendrites, while the changes in pyramidal neurons located in other layers of the cerebral cortex are on a much smaller scale (Miller, 1988). Therefore, the pyramidal neurons of layer $\mathrm{V}$ may also depend on NMDAR-L mediated neurotrophic actions (Pearce et al., 1987).

The restricted laminar expression of NMDAR-L during most phases of cortical development differs from other glutamate receptor subunits, which appear to be expressed in multiple cortical layers during all stages of cortical development (Monyer et al., 1991; Laurie et al., 1994; Monyer et al., 1994). Laminaspecific expression has been described previously for some growth factors and growth factor receptors, homeobox genes, and other transcription factors (Huntley et al., 1992; Ip et al.,

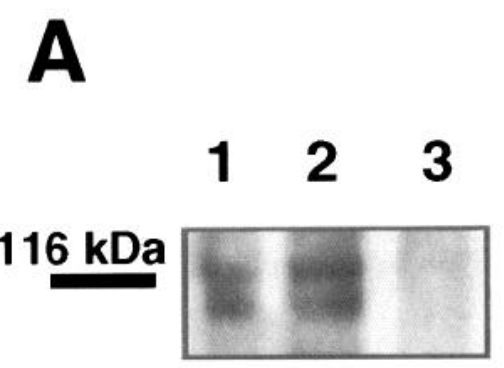

B

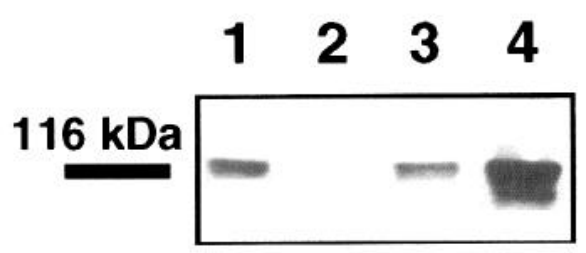

Figure 10. A, Immunodetection of NMDAR1 in Xenopus oocytes. Oocyte membrane proteins were subjected to immunoprecipitation followed by SDS-PAGE and immunoblotting using a mono-clonal NMDAR1 antibody. Lane 1 , oocytes $(n=40)$ injected with cRNA ( $~ 30$ ng/subunit) to NMDAR1, NMDAR2B, and NMDAR-L. Lane 2, oocytes $(n=40)$ injected with cRNA $(\sim 30 \mathrm{ng} / \mathrm{subunit})$ to NMDAR1 and NMDAR2B. Lane 3, native oocytes $(n=40) . B$, Immunodetection of NMDAR1 in HEK 293 cells. HEK 293 membrane proteins $(1 \mathrm{mg})$ were subjected to immunoprecipitation followed by SDS-PAGE and immunoblotting using a monoclonal NMDAR1 antibody. Lane 1 , cells transfected with $\mathrm{cDNA}(\sim 10$ $\mu \mathrm{g} /$ subunit) corresponding to NMDAR1, NMDAR2B, and NMDAR-L. Lane 2, cells transfected with cDNA ( $\sim 10 \mu \mathrm{g} / \mathrm{subunit})$ corresponding to NMDAR2B and NMDAR-L. Lane 3, cells transfected with cDNA $(\sim 10 \mu \mathrm{g})$ corresponding to NMDAR1 and NMDAR2B. Lane 4, cells transfected with cDNA $(\sim 20 \mu \mathrm{g})$ corresponding to NMDAR1. 
1993; Leifer et al., 1993; Frantz et al., 1994). Therefore, expression of the NMDAR-L gene may be linked to the expression of homeobox genes and other transcription factors. A precedent for the latter possibility is illustrated by the finding that the expression of $C N S-1$, a POU homeodomain gene that is expressed in cerebellar neurons, is upregulated following activation of cerebellar NMDA receptors (Bulleit et al., 1994).

The expression of the NMDAR-L gene in the mature rodent brain is limited to the nucleus of the lateral olfactory tract, a small nucleus in the forebrain, that is interconnected with the piriform cortex, the olfactory tubercle, other olfactory areas, and the basolateral amygdala (Price, 1973; Broadwell, 1975; Krettek and Price, 1978). A substantial proportion of the centrifugal fibers innervating the olfactory bulb originate from this nucleus (De Olmos et al., 1978; Haberly and Price, 1978). Furthermore, this nucleus, in contrast to most other areas of the forebrain, is predominantely innervated by cholinergic fibers that lack NGF receptor immunoreactivity (Heckers and Mesulam, 1994). It will be of interest therefore to examine NMDAR-L expression in the nucleus of the lateral olfactory tract under conditions of axonal regeneration and new synapse formation in the light of the potential influence of neurotransmitters on these processes.

\section{Note added in proof}

During the course of this work, we learned that a clone identical to NMDAR-L had been obtained independently and named $\chi^{-1}$ by Ciabarra et al. (1995). We generated data largely in accord, communicated our results freely with one another, and now publish the work as contiguous articles.

\section{References}

Agmon A, Yang LT, O'Dowd DK, Jones EG (1993) Organized growth of thalamocortical axons from the deep tier of terminations into layer IV of developing mouse barrel cortex. J Neurosci 13:5365-5382.

Agmon A, Yang LT, Jones EG, O'Dowd DK (1995) Topological precision in the thalamic projection to neonatal mouse barrel cortex. $\mathbf{J}$ Neurosci 15:549-561.

Aizenman E, Lipton SA, Loring RH (1989) Selective modulation of NMDA responses by reduction and oxidation. Neuron 2:1257-1263.

Araki K, Meguro H, Kushiya E, Takayama C, Inoue Y, Mishina M (1993) Selective expression of the glutamate receptor channel delta 2 subunit in cerebellar Purkinje cells. Biochem Biophys Res Commun 197:1267- 1276.

Bear MF, Kleinschmidt A, Gu QA, Singer W (1990) Disruption of experience-dependent synaptic modifications in striate cortex by infusion of an NMDA receptor antagonist. J Neurosci 10:909-925.

Berry M, Rogers AW (1965) The migration of neuroblasts in the developing cerebral cortex. J Anat 99:691-709.

Boulter J, Hollmann M, O'Shea-Greenfield A, Hartley M, Deneris E, Maron C, Heinemann S (1990) Molecular cloning and functional expression of glutamate receptor subunit genes. Science 249:10331037.

Broadwell RD (1975) Olfactory relationships of the telencephalon and diencephalon in the rabbit. I. An autoradiographic study of the efferent connections of the main and accessory olfactory bulbs. J Comp Neurol 163:329- 346.

Brose N, Huntley GW, Stern-Bach Y, Sherma G, Morrison JH, Heinemann SF (1994) Differential assembly of coexpressed glutamate receptor subunits in neurons of rat cerebral cortex. J Biol Chem 269: 16780-16784.

Bulleit RF, Cui H, Wang J, Lin X (1994) NMDA receptor activation in differentiating cerebellar cell cultures regulates the expression of a new POU gene, Cns-1. J Neurosci 14:1584-1595.

Burnashev N, Schoepfer R, Monyer H, Ruppersberg JP, Gunther W, Seeburg PH, Sakmann B (1992) Control by asparagine residues of calcium permeability and magnesium blockade in the NMDA receptor. Science 257:1415-1419.

Ciabarra AM, Sullivan JM, Gahn LG, Pecht G, Heinemann S, Sevarino KA (1995) Cloning and characterization of $\chi-1$ : a developmentally regulated member of a novel class of the ionotropic glutamate receptor family. J Neurosci 15:6498-6508.

Cline HT, Debski EA, Constantin-Paton M (1987) NMDA receptor antagonist desegregates eye-specific stripes. Proc Natl Acad Sci USA $84: 4342-4345$

Collingridge GL, Singer W (1990) Excitatory amino acid receptors and synaptic plasticity. Trends Pharmacol Sci 11:290-296.

De Carlos JA, O'Leary DDM (1992) Growth and targeting of subplate axons and establishment of major cortical pathways. J Neurosci 12: $1194-1211$.

De Olmos JSH, Hardy H, Heimer L (1978) The afferent connections of the main and the accessory bulb formations in the rat: an experimental HRP-study. J Comp Neurol 181:213-244.

Farrant M, Feldmeyer D, Takahashi T, Cull-Candy SG (1994) NMDAreceptor channel diversity in the developing cerebellum. Nature 368 : 335-339.

Forrest D, Yuzaki M, Soares HD, Ng L, Luk DC, Sheng M, Stewart CL, Morgan JI, Connor JA, Curran T (1994) Targeted disruption of NMDA receptor 1 gene abolishes NMDA response and results in neonatal death. Neuron 13:325-338.

Frantz GD, Bohner AP, Akers RM, McConnell SK (1994) Regulation of the POU domain gene SCIP during cerebral cortical development. J Neurosci 14:472- 485 .

Haberly, Price JL (1978) Association and commissural fiber systems of the olfactory cortex of the rat. I. Systems originating in the piriform cortex and adjacent areas. J Comp Neurol 178:711-740.

Hahm J-O, Langdon RB, Sur M (1991) Disruption of retinogeniculate afferent segregation by antagonists to NMDA receptors. Nature 351 : $568-570$.

Heckers S, Mesulam MM (1994) Two types of cholinergic projections to the rat amygdala. Neuroscience 60:383-397.

Hicks SP, D'Amato CJ (1968) Cell migration to the isocortex in the rat. Anat Rec 160:619-634.

Hollmann M, O'Shea-Greenfield A, Rogers SW, Heinemann S (1989) Cloning by functional expression of a member of the glutamate receptor family. Nature 342:643-648

Huntley GW, Benson DL, Jones EG, Isackson PJ (1992) Developmental expression of brain derived neurotrophic factor mRNA by neurons of fetal and adult monkey prefrontal cortex. Dev Brain Res 70:5363.

Huntsman MM, Isackson PJ, Jones EG (1994) Lamina-specific expression and activity-dependent regulation of seven $\mathrm{GABA}_{\mathrm{A}}$ receptor subunit mRN $\Lambda s$ in monkey visual cortex. J Neurosci 14:2236-2259.

Ip NY, McClain J, Barrezueta NX, Aldrich TH, Pan L, Li Y, Wiegand SJ, Friedman B, Davis S, Yancopolous GD (1993) The $\alpha$ component of the CNTF receptor is required for signaling and defines potential CNTF targets in the adult and during development. Neuron 10:89102

Ishii T, Moriyoshi K, Sugihara H, Sakurada K, Kadotani H, Yokoi M, Akazawa C, Shigemoto R, Mizuno N, Masu M, Nakanishi S (1993) Molecular characterization of the family of the NMDA receptor subunits. J Biol Chem 268:2836-2843.

Kawajiri S, Dingledine R (1993) Multiple structural determinants of voltage-dependent magnesium block in recombinant NMDA receptors. Neuropharmacology 32:1203-11.

Kleinschmidt A, Bear MF, Singer W (1987) Blockade of "NMDA" receptors disrupts experience-dependent plasticity of kitten striate cortex. Science 238:355-358.

Koester SE, O'Leary DDM (1992) Functional classes of cortical projection neurons develop dendritic distinctions by class-specific sculpting of an early common pattern. J Neurosci 12:1382-1393.

Köhr G, F,ckardt S, I uddens H, Monyer H, Seehurg P (1994) NMDA receptor channels: subunit-specific potentiation by reducing agents. Neuron 12:1031- 1040.

Komuro H, Rakic P (1992) Sclective rolc of N-type calcium channels in neuronal migration. Science 257:806-809.

Komuro H, Rakic P (1993) Modulation of neuronal migration by NMDA receptors. Science 260:95-107.

Kozak M (1991) Structural features in eukaryotic mRNAs that modulate the initiation of translation. J Biol Chem 266:19867-19870.

Krettek JE, Price JL (1978) A description of the amygdaloid complex in the rat and cat with observations in intra-amygdaloid axonal connections. J Comp Neurol 178:255-280.

Laube B, Kuryatov A, Kuhse J, Betz H (1993) Glycine-glutamate in- 
teractions at the NMDA receptor: role of cysteine residues. FEBS Lett 335:331-334.

Laurie DJ, Seeburg PH (1994) Regional and developmental heterogeneity in splicing of the rat brain NMDAR1 mRNA. J Neurosci 14: $3180-3194$.

Leifer D, Krainc D, Yu Y-T, McDermott J, Breitbart RE, Heng J, Neve RL, Kosofsky B, Nadal-Ginard B, Lipton SA (1993) MEF2C, a MADS/MEF2-family transcription factor expressed in a laminar distribution in cerebral cortex. Proc Natl Acad Sci USA 90:1546-1550.

Li Y, Erzurumlu RS, Chen C, Jhaveri S, Tonegawa S (1994) Whiskerrelated neuronal patterns fail to develop in the trigeminal brainstem nuclei of NMDAR1 knockout mice. Cell 76:427-437.

I.ipton SA, Kater SB (1989) Neurotransmitter regulation of neuronal outgrowth, plasticity and survival. Trends Neurosci 12:265-270.

Miller MW (1988) Development of projection and local circuit neurons inneocortex. In: Cerebral cortex. Development and maturation of cerebral cortex (Peters A, Jones EG, eds), pp 133-175. New York: Plenum.

Monyer H, Seeburg PH, Wisden W (1991) Glutamate-operated channels: developmentally early and mature forms arise by alternative splicing. Neuron 6:799-810.

Monyer H, Sprengel R, Schoepfer R, Herb A, Higuchi M, Lomeli H, Burnashev N, Sakmann B, Seeburg PH (1992) Heteromeric NMDA receptors: molecular and functional distinction of subtypes. Science 256:1217-1221.

Monyer H, Burnashev N, Laurie DJ, Sakmann B, Seeburg PH (1994) Developmental and regional expression in the rat brain and functional expression of four NMDA receptors. Neuron 12:529-540.

Moriyoshi K, Masu M, Ishii T, Shigemoto R, Mizuno N, Nakanishi S (1991) Molecular cloning and characterization of the rat NMDA receptor. Nature 354:31-37.

Nakanishi S (1992) Molecular diversity of glutamate receptors and inplications for brain function. Science 258:597-603

O'Leary DDM, Koester SE (1993) Development of projection neuron types, axon pathways, and patterned connections in the mammalian cortex. Neuron 10:991-1006.

Pearce IA, Cambray-Deakin MA, Burgoyne RD (1987) Glutamate acting on NMDA receptors stimulate neurite outgrowth from cerebellar granule cells. FEBS Lett 233:143-147.

Price JL (1973) An autoradiographic study of complementary laminar patterns of termination of afferent fibers to the olfactory cortex. I Comp Neurol 150:87-108.

Rakic P (1972) Mode of cell migration to the superficial layers of fetal monkey neocortex. J Comp Neurol 145:61-84.

Rakic P, Sidman RL (1973) Weaver mutant mouse cerebellum: defective neuronal migration secondary abnormality of Bergmann glia. Proc Natl Acad Sci USA 70:240-244.

Sakurada K, Masu M, Nakanishi S (1993) Alteration of $\mathrm{Ca}^{2+}$ permeability and sensitivity to $\mathrm{Mg}^{2+}$ and channel blockers by a single amino acid substitution in the NMDA receptor. J Biol Chem 268:410415 .

Schlaggar BL, Fox K, O’Leary DDM (1993) Postsynaptic control of plasticity in developing somatosensory cortex. Nature 364:623-626.
Schreyer DJ, Jones EG (1982) Growth and target finding by axons of the corticospinal tract in prenatal and postnatal rats. Neuroscience 7:1837-1853

Senft S, Woolsey T (1991) Growth of thalamic afferents into mouse barrel cortex. Cereb Cortex 1:308-335.

Shatz CJ (1990) Impulse activity and the patterning of connections during CNS development. Neuron 5:745-756.

Shatz CJ, Chun JJM, Luskin MB (1988) The role of the subplate in the development of the mammalian telencephalon. In: Cerebral cortex. Development and maturation of cerebral cortex (Peters A, Jones EG, eds), pp 35-58. New York: Plenum.

Sheng M, Cummings J, Roldan L, Jan Y, Jan L (1994) Changing subunit composition of heteromeric NMDA receptors during development of rat cortex. Nature 368:144-147.

Simon D, Prusky G, O'Leary D, Constantine-Paton M (1992) N-Methyl-D-aspartate receptor antagonists distupt the formation of a mammalian neural map. Proc Natl Acad Sci USA 89:10593-10597.

Sommer B, Köhler M, Sprengel R, Seeburg PH (1991) RNA editing in brain controls a determinant of ion flow in glutamate-gated channels. Cell 67:11- 19 .

Stanfield BB, O'Leary DDM (1985) The transient corticospinal projection from the occipital cortex during the postnatal development of the rat. J Comp Neurol 238:236-248.

Stanfield BB, O'Leary DDM, Fricks C (1982) Selective elimination in early postnatal development restricts cortical distribution of rat pyramidal tract neurons. Nature 298:371-373.

Sucher NJ, Wong LA, Lipton SA (1990) Redox modulation of NMDA receptor-mediated $\mathrm{Ca}^{2+}$ flux in mammalian central neurons. Neuroreport 1:29-32.

Sucher NJ, Brose N, Deitcher DL, Awobuluyi M, Gasic GP, Bading H, Cepko CL, Greenberg ME, Jahn R, Heinemann SF, Lipton SA (1993) Expression of endogenous NMDAR1 transcripts without receptor protein suggests post-transcriptional control in PC12 cells. J Biol Chem 268:22299-22304.

Sullivan JM, Traynelis SF, Chen HSV, Escobar W, Heinemann SF, Lipton SA (1994) Identification of two cysteine residues that are required for redox modulation of the NMDA subtype of glutamate receptor. Neuron 13:929- 936 .

Wafford KA, Bain CJ, Le BB, Whiting PJ, Kemp JA (1993) Preferential co-assembly of recombinant NMDA receptors composed of three different subunits. Neuroreport 4:1347-1349.

Watanabe M, Inoue Y, Sakimura K, Mishina M (1992) Developmental changes in distribution of NMDA receptor channel subunit mRNAs. Neuroreport 3:1138-1140.

Watanabe M, Inoue Y, Sakimura K, Mishina M (1993) Distinct distributions of five $N$-methyl-D-aspartate receptor channel subunit mRNAs in the forebrain. J Comp Neurol 338:377-390.

Wise SP, Jones EG (1976) The organization and postnatal development of the commissural projection to the somatic sensory cortex of the rat. J Comp Neurol 168:313-344.

Wise SP, Jones EG (1977) Cells of origin and terminal distribution of descending projections of the rat somatic sensory cortex. J Comp Neurol 175:129-158. 